\title{
Proposal of managerial standards for new product portfolio management in Brazilian pharmaceutical companies
}

\author{
Raquel Assis Moreira*, Lin Chih Cheng
}

Quality and Innovation Technology Center (NTQI), Production Engineering Department, Federal University of Minas Gerais

\begin{abstract}
New Product Portfolio Management is aimed at helping decision-makers better select projects for new products based on key criteria for the manufacturer. The Brazilian pharmaceutical industry has been undergoing change due to stricter sanitary requirements following the enactment of the Generic Law in 1999. This paper presents the results of a research study aimed at clarifying the rationale employed by national pharmaceutical companies in selecting and prioritizing their new product development projects. Consequently, proposals for an analytical structure that could help these companies better select their products were produced. The research was carried out using case study methodology in which four different companies were investigated. The results of the field study confirmed that these companies had a non-structured Product Development System and that the selection of new product development projects was made on a non-systematic basis. The research also identified key criteria for the selection of projects of new pharmaceutical products, which provided the basis for the preparation of a proposal for a managerial standard for application of New Product Portfolio Management.
\end{abstract}

Uniterms: Portfolio management. Pharmaceutical products/development. Pharmaceutical industry. Brazil/pharmaceutical industry.

A gestão de portfólio de projetos de novos produtos visa a auxiliar os tomadores de decisão a selecionar projetos de novos produtos considerando critérios importantes para a organização. A indústria farmacêutica brasileira tem passado por transformações devido ao aumento das exigências sanitárias após a Lei de Genéricos, de 1999. O objetivo deste trabalho foi entender como as indústrias farmacêuticas brasileiras selecionam seus projetos de desenvolvimento de novos produtos e propor uma estrutura que possa auxiliar estas empresas a selecionar seus projetos de produtos. Foi utilizada a metodologia de estudo de caso e uma mostra de quatro organizações foi investigada. Os resultados indicam que essas empresas apresentam um desenvolvimento de produtos não estruturado e que a seleção de projetos de novos produtos é realizada de forma não-sistemática. Critérios importantes para a seleção de projetos de novos produtos foram identificados e utilizados para elaboração de um padrão gerencial para aplicação da gestão de portfólio de projetos de novos produtos.

Unitermos: Gestão de portfólio. Produtos farmacêuticos/desenvolvimento. Indústria farmacêutica. Brasil/indústria farmacêutica.

\section{INTRODUCTION}

The new product development process is intrinsically risky. Studies show that only approximately $60 \%$ of the products launched are subsequently considered commercially successful (Griffin, 1997). In the global

\footnotetext{
*Correspondence: R. A. Moreira. Núcleo de Tecnologia da Qualidade e da Inovação (NTQI), Departamento de Engenharia de Produção, Universidade Federal de Minas Gerais - UFMG. Av. Presidente Antônio Carlos, 6627 (Campus da Pampulha) - CEP 31270-901 - Belo Horizonte - MG, Brazil. E-mail: rmoreira@sjm.com
}

pharmaceutical industry, the innovative medicine development process is even more challenging because of long development times, low success rates, high capital requirements for building a manufacturing facility, and great uncertainty in sales estimates (Blau et al., 2004).

Brazilian pharmaceutical research consists basically of the development of formulations for administration of drugs whose patents have expired. The development of similar and generic medicines is important for the country as it increases the competitiveness in the sector, thus favoring a price reduction and increasing the population's access 
to medicines. The generic medicines are interchangeable with patented medicines, presenting the same quality but at lower prices (Moreira, 2008). Generics can be defined as copies of drugs, based on the same active substance as the patented medicine, which are labeled with the active substance of the drug. Similar medicines are manufactured as generic medicines but are labeled with their own brand-name.

The Brazilian pharmaceutical industry has undergone changes to its management processes after the enactment of the Generic Law (Law 9787) in 1999. The stricter sanitary requirements have required an effective quality system and better strategic planning for new product development. Consequently, the selection of new pharmaceutical product projects in the home industry requires a systematic process to support decision making. The new product portfolio management has the purpose of guiding this process.

Cooper, Edgett and Kleinschmidt (1997) define portfolio management as a dynamic decision process, whereby a business's list of active new product projects is constantly updated and revised. In this process, new projects are evaluated, selected and prioritized. Thus, portfolio management is a process for making decisions and allocating resources. Portfolio management has three main objectives: to develop projects strategically aligned with the business's strategy; to maximize portfolio value; and to balance projects in terms of a number of parameters. This paper has the overall aim of ascertaining how the Brazilian pharmaceutical companies select their new product development projects. A structure is then proposed that can help these companies better select their products.

\section{Portfolio Management}

Portfolio management-PM, is part of the strategic dimension of product development management. Research on new product portfolio management presents a quantitative and qualitative dimension approach. The qualitative approach employs classifications, charts and diagrams such as scoring models and bubble diagrams. These approaches are described in the papers published by Bitman (2005), Mikkola (2001), Cooper, Edgett and Kleinschmidt (1998), and Roussel, Saad and Bohlin (1992). The quantitative approach employs mathematical methods in order to obtain data that support project selection. The quantitative approach is outlined in studies by Santiago and Vakili (2005), Blau et al. (2004), Loch and Kavadias (2001), Heidenberger and Stummer (1999). Some common points are shared in the discussions among the authors of different research lines: the dynamism of the environment, and the interdependence of projects (Santiago, Vakili, 2005; Blau et al., 2004; Loch, Kavadias, 2001; Archer, Ghasemzadeh, 1999; Cooper, Edgett, Kleinschmidt, 1998).

Portfolio management models are frequently found in the literature and all share the objective of providing a methodology to guide the project selection process. The assessed portfolio management models and their main characteristics are presented in Figure 1. The identified characteristics in the Figure are as follows: i) focus of the model - the purpose for which the model was created; ii) sequence - the existence of defined steps for application of the model; iii) flexibility - the possibility of using different selection techniques; iv) time scale - the identification of either consecutive or simultaneous steps that guide the application of the model; $v$ ) continuous - a cyclic application of the model; vi) systemic - the incorporation of the organizational levels (strategic, tactical and operational) comprising the organizational system; vii) important characteristics - any peculiar features of the model that should be mentioned.

The portfolio management models encompass the use of different techniques that should be chosen by the company, taking into consideration their ease-of-use, available resources and time, and the team's familiarity with the technique. The project selection techniques provide data or visual representations that allow the characterization, comparison, evaluation and, consequently, selection of projects. Hall and Nauda (1990) and Heidenberger and Stummer (1999) classify the project selection techniques, which facilitates the choice of the most appropriate technique.

Each portfolio management model presents specific characteristics, either to guide a certain economic activity or to refine a model previously described in the literature, or to take into consideration specificity by selecting projects with a high degree of interdependence, or selecting ongoing projects. Costello (1983) presented a bibliographic review of six project selection models developed in the 1960s and 1970s. There is a point in common among all the portfolio management models assessed: successful application depends on the choice of the project selection criteria. The literature presents some standard criteria (Oliveira, Rozenfeld, 2007; Bitman, 2005; Cooper, Edgett, Kleinschmidt, 1997), but each company needs to evaluate the importance of a given criterion to its business.

\section{Development of a portfolio management model for Brazilian pharmaceutical companies}

Given the absence of a portfolio management model 


\begin{tabular}{|c|c|c|c|c|c|c|c|c|}
\hline Author & $\begin{array}{c}\text { Cooper et al. } \\
\text { (1998) }\end{array}$ & $\begin{array}{c}\text { Archer and } \\
\text { Ghasemzadeh } \\
\text { (1999) }\end{array}$ & $\begin{array}{c}\text { Kavadias } \\
\text { (2001) }\end{array}$ & $\begin{array}{l}\text { Bitman and } \\
\text { Sharif (2007) }\end{array}$ & Correia (2005) & Pereira (2002) & Oliveira (2007) & Costello (1983) \\
\hline $\begin{array}{l}\text { Focus of the } \\
\text { model }\end{array}$ & New products & Projects & Projects & New products & $\begin{array}{l}\text { Software } \\
\text { projects }\end{array}$ & $\begin{array}{l}\text { New products } \\
\text { and services }\end{array}$ & $\begin{array}{l}\text { New dressing } \\
\text { products }\end{array}$ & Projects \\
\hline Sequence & partial & yes & no & yes & Yes & no & yes & yes \\
\hline Flexibility & Yes & yes & yes & no & Yes & yes & yes & yes \\
\hline Time scale & No & yes & no & partial & partial & no & partial & yes \\
\hline Continuous & Yes & no & yes & yes & Yes & yes & no & no \\
\hline Systemic & Yes & no & yes & yes & Yes & yes & yes & yes \\
\hline $\begin{array}{l}\text { Important } \\
\text { characteristic }\end{array}$ & $\begin{array}{l}\text { Interconnection } \\
\text { between } \\
\text { operational } \\
\text { and strategic } \\
\text { dimensions }\end{array}$ & $\begin{array}{l}\text { Logical sequence } \\
\text { of the steps } \\
\text { facilitates practical } \\
\text { application }\end{array}$ & $\begin{array}{c}\text { Quantitative } \\
\text { analysis }\end{array}$ & $\begin{array}{c}\text { Created from } \\
\text { analyses with } \\
\text { Research and } \\
\text { Development } \\
\text { managers }\end{array}$ & $\begin{array}{l}\text { Emphasizes } \\
\text { the importance } \\
\text { of Knowledge } \\
\text { Management }\end{array}$ & $\begin{array}{l}\text { Applied in } \\
\text { a private } \\
\text { research and } \\
\text { development } \\
\text { institute }\end{array}$ & $\begin{array}{l}\text { Created to } \\
\text { meet a clothing } \\
\text { company's } \\
\text { needs }\end{array}$ & $\begin{array}{l}\text { Use of the } \\
\text { time scale and } \\
\text { incorporation } \\
\text { of all the } \\
\text { hierarchical } \\
\text { levels }\end{array}$ \\
\hline
\end{tabular}

FIGURE 1 - Portfolio Management models assessed and their characteristics.

for pharmaceutical companies manufacturing generic or similar medicines, a reference model to be used during the case studies was required. The Portfolio Management model proposed by Cooper, Edgett and Kleinschmidt (1998) was chosen to be used as the basis for theoretical reference. The reasons that justify this choice are as follows: i) it is specific for new product portfolio management; ii) the model presents an integration between the strategic and tactic levels of the company; iii) it is managerial in nature, i.e. it is not merely a sequence of steps; iv) the model is adaptable to the company's criteria and strategies; v) the model stimulates the evolution of Product Development Management (PDM) in the company. Successful portfolio management depends on the choice of criteria. The portfolio management in the pharmaceutical industry should take into consideration, besides the standard criteria such as those presented by Oliveira and Rozenfeld (2007), Cooper, Edgett and Kleinschmidt (1997) and Bitman (2005), some specific criteria, namely, social relevance, expiration of patents, raw material availability and sanitary legislation.

\section{Social Relevance}

The social relevance of a product can be defined as the impact a given product has on public health. The pursuit of a financial return for new products is unquestionable. However, considering the importance of a pharmaceutical product to people's quality of life and life expectation, it is essential to stimulate the development of new products that contribute to this end.

The social relevance of new pharmaceutical products is evident in the development of i) new drugs for rare diseases that are not of great commercial interest because of the low demand for them; ii) new drugs for neglected diseases which are not of commercial interest since these diseases only afflict poor countries; iii) vaccines that reduce the incidence of diseases and, consequently, present decreasing financial returns; iv) medicines with low financial return that meet basic public health needs; v) phytotherapeutic medicines that can be low cost and meet basic public health needs, and also keep the popular culture active. Moreira (2008) describes each of these cases in her research.

\section{Monitoring of patents}

It is widely known that the Brazilian pharmaceutical industry concentrates its R\&D (Research \& Development) activities on pharmaceutical-technical development and creates practically no new molecules. Pharmaceuticaltechnical development consists basically of the development of formulations for administration of drugs whose patents have expired and which lead to generic or similar medicines.

The generic and similar medicine industry only grows because of the increased R\&D of innovative medicines. After expiration of the patents of these innovative medicines, all companies are allowed to manufacture the medicine. This situation offers a virtually free asset to the companies manufacturing generic and similar medicines, which are allowed to trade their medicines replacing the innovative products at very low prices, typically reduced by approximately $40 \%$ (ANVISA, 2002). The main patented products, whose current sales exceed one billion units worldwide and whose patents are set to expire within the next five years, are worth 80 billion dollars in terms of projected sales. This situation provides the companies manufacturing generic and similar medicines with growth opportunities (IFPMA, 2004). For this reason the monitoring of patents due to expire is essential to the portfolio management of the generic and similar medicine pharmaceutical industry. 


\section{Sanitary legislation}

Sanitary legislation has a great impact on pharmaceutical R\&D. A recent study has reported an estimated cost of 802 million dollars to perform an innovative medicine development process, from the selection of molecules to market launch. In the 1980s and 1990s, the estimated cost amounted to 230 and 500 million dollars, respectively (EFPIA, 2004). These costs have increased sharply because of the increased number of patients required for clinical trials and the increased number of clinical tests per order of new medicine (THE BOSTON, 1993).

In the home pharmaceutical industry, the impact of the stricter sanitary legislation is notable. In January 1999, the enforcement of Generic Law (Law 9787) changed the structure of the pharmaceutical segment. It is unquestionable that this resulted in stricter control of the safety and quality of the medicines offered to the population, as well as in broader access to these products, in view of the competitiveness and reduced prices. This stricter control of the safety and quality of the medicines stems from the required bioequivalence and pharmaceutical equivalence tests. These tests are performed by laboratories qualified and/or certified by ANVISA, which compare the generic medicines to their respective patented reference medicines. In May 2003, new changes were made to the technical regulations related to medicine registration, such as the requirement of pharmaceutical equivalence and relative bioavailability tests for registration of similar medicines, as was already required for generic medicines (ANVISA, 2006). These changes have impacted the PDM in the Brazilian pharmaceutical industry, because higher financial investments have been needed to defray the new tests.

The sanitary legislation is a criterion that should be taken into account in Portfolio Management, since the company needs to define which type of medicine shall be registered. Each type of medicine has its own specific legislation and requires different financial investments. Besides this, the marketing strategy of a similar medicine is different to that of a generic medicine. A similar medicine has a trade name that needs to be made known to be traded, which is not applicable to the generic medicine.

\section{Raw material availability}

Raw material availability impacts the portfolio management of Brazilian pharmaceutical companies. Brazil is highly dependent on the import of pharmaceutical chemical substances, and active substance manufacturers are required to meet several regulatory requirements for ANVISA registration of the product. The sanitary legislation for product registration requires evidence of the quality of the pharmaceutical chemical substance and supplier qualification. The results of the bioequivalence and bioavailability tests are also influenced by the physical characteristics of the raw materials. Consequently, the company needs to be sure it will be able to purchase the raw material in the necessary quantity and quality and at a compatible cost. The level of difficulty in purchasing the suitable raw material impacts the product launch time.

The portfolio management model proposed by Cooper, Edgett and Kleinschmidt (1998) and the specific criteria for the Brazilian pharmaceutical companies served as the theoretical reference for these case studies.

\section{MATERIAL AND METHODS}

Case studies are an empirical investigation that examine a contemporary phenomenon within its context, especially where the limits between the phenomenon and the context are not clearly defined. This method has been the preferred strategy in dealing with "how" and "why" research issues, when the researcher has little control over events and when the focus is on contemporary phenomena occurring in some real life context (YIN, 2005).

In this paper, the method has been conducted according to Figure 2. The figure shows that the initial step in designing the study consists of the development of the theory. The theory has been developed from the review of the literature, followed by the selection of cases and development of protocol. The protocol presents the research problem, the theoretical basis and the data collection guidelines. The guidelines contain the selected cases, the form of contact with the companies, the preparation to visit the company, the interview questionnaire and the documents to be requested from the company. The case studies were performed individually. After the individual analysis of the cases, a crossed analysis of the cases was performed, in order to reach conclusions about replication and divergent results. The theory was revised based on this analysis, and a final conclusion was reached leading to a proposal of a managerial standard for portfolio management in Brazilian pharmaceutical companies.

Given that the Brazilian pharmaceutical sphere encompasses two types of medicine companies - private pharmaceutical companies and official laboratories (government sponsored laboratories), it was decided to select at least one company of each type in order to replicate the results. Case studies were performed involving three private companies ( $\mathrm{P} 1, \mathrm{P} 2$ and $\mathrm{P} 3)$ and one official laboratory $(\mathrm{O} 1)$. The main data collection instrument was the semi-structured qualitative interview. As defined in the protocol, interviews with professionals related to the 


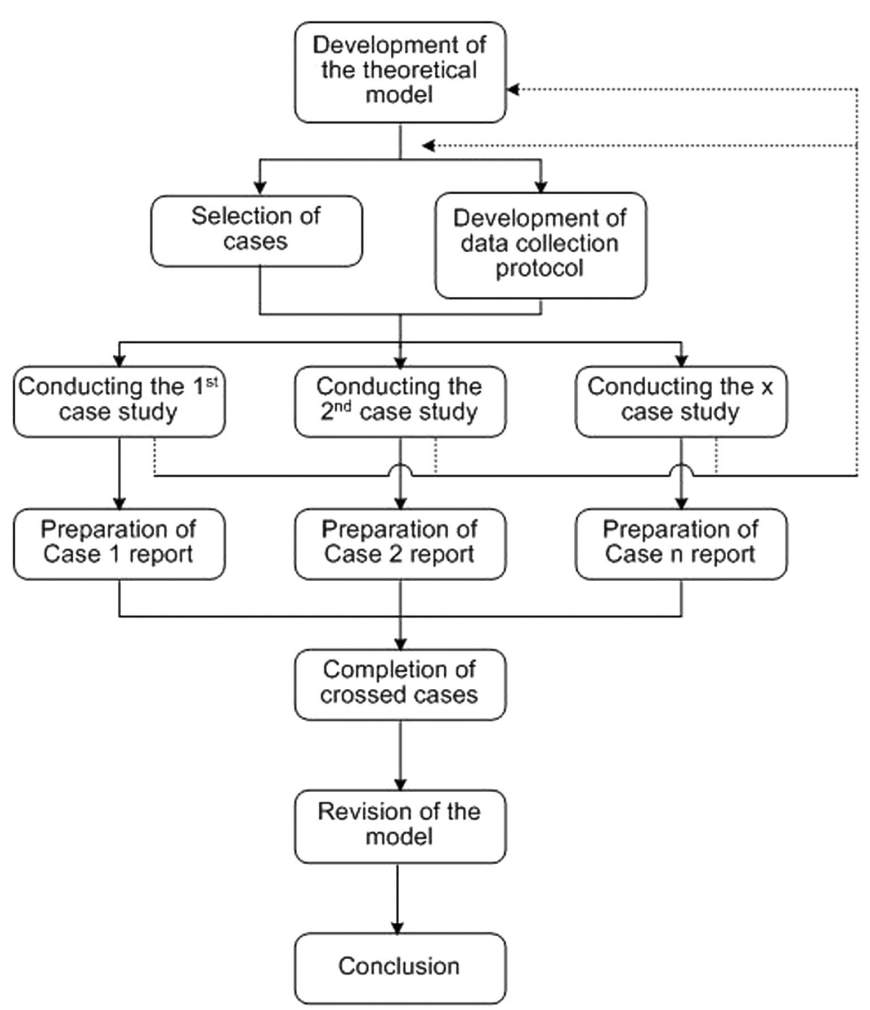

SOURCE: adapted from YIN (2005)

FIGURE 2 - Research method used.

product development process were scheduled. The other forms of data collection consisted of observations of the work environment, reference to documents made available by the company and to information available on ANVISA's electronic website.

\section{RESULTS AND DISCUSSION}

The case study in this paper was not intended to validate a portfolio management model for Brazilian pharmaceutical companies. The intention was to establish the important criteria for portfolio management in these companies, to understand how they have been used to select new product development projects and to develop a tool to help these companies better define their portfolios. The characteristics of the assessed companies are presented in Figure 3.

The case studies confirmed that the Brazilian pharmaceutical companies are dedicated to the development of formulations and not to creating novel drugs. Several official laboratories have research departments, but few studies focus on the development of new medicines. The purposes of portfolio management described by Cooper, Edgett and Kleinschmidt (1998) are suited to the Brazilian pharmaceutical industry. The official laboratories emphasized strategic alignment by means of the criterion of social relevance whereas value maximization was strongly present in the private laboratories.

The private companies have pursued improved team working. The official laboratory assessed is beginning to set up multidisciplinary work teams. None of the assessed companies was found to have a multidisciplinary PDM team. The professionals of the product development sector

\begin{tabular}{|c|c|c|c|c|}
\hline Company Code & P1 & P2 & P3 & 01 \\
\hline Location & Minas Gerais & Minas Gerais & Minas Gerais & Southeast \\
\hline Number of employees & 320 & 210 & 480 & 425 \\
\hline Built-up area $\left(m^{2}\right)$ & 12000 & 3860 & 6900 & Not informed \\
\hline $\begin{array}{l}\text { Annual gross revenues }(R \$ \\
\text { millions) }\end{array}$ & 35 & 25 & $>20$ & Not informed \\
\hline Number of traded products & 83 & 68 & 50 & 43 \\
\hline GMP Certification & yes & Yes & yes & yes \\
\hline $\begin{array}{l}\text { Position of the interviewees and } \\
\text { time in the company }\end{array}$ & $\begin{array}{c}\text { Development Manager- } \\
5.5 \text { years / } \\
\text { Industrial Director }-6 \text { years }\end{array}$ & $\begin{array}{c}\text { Development coordinator - } \\
3 \text { years / Industrial Director - } \\
5 \text { years }\end{array}$ & $\begin{array}{l}\text { Development Manager - } \\
6 \text { years }\end{array}$ & $\begin{array}{c}\text { Development coordinator - } \\
3 \text { years }\end{array}$ \\
\hline Average development time & 2 years & 2 years & 2 years & 3 years \\
\hline Number of launches in 2007 & 2 & 3 & 8 & 2 \\
\hline$P D P$ & informal & None & formal & formal \\
\hline Team responsible for development & Development laboratory team & Development laboratory team & Multidisciplinary team & Development laboratory team \\
\hline Partnerships with research centers & None & Only for phytotherapeutic medicines & None & yes \\
\hline Financial planning & None & None & None & None \\
\hline Satisfaction with the results & Low & Medium & Low & Low \\
\hline New product selection process & $\begin{array}{l}\text { informal, performed by the commercial } \\
\text { board of directors with focus on the cost } \\
\text { analysis }\end{array}$ & $\begin{array}{l}\text { informal, performed by the commercial } \\
\text { board of directors with focus on the cost } \\
\text { analysis }\end{array}$ & $\begin{array}{l}\text { informal, performed by the management } \\
\text { with focus on the cost analysis }\end{array}$ & $\begin{array}{l}\text { informal, performed by the president and } \\
\text { development manager }\end{array}$ \\
\hline Development strategy & informal & Informal & informal & Non-structured \\
\hline $\begin{array}{l}\text { Number of products under } \\
\text { development }\end{array}$ & 100 & 62 & 24 & 33 \\
\hline
\end{tabular}

FIGURE 3 - Characteristics of the companies studied. 


\begin{tabular}{|c|c|c|c|c|}
\hline Criterion & 01 & P1 & P2 & P3 \\
\hline Monitoring of patents & $\begin{array}{c}\text { Does not interfere } \\
\text { with portfolio } \\
\text { management }\end{array}$ & Not performed & $\begin{array}{c}\text { Monitors patents, } \\
\text { but result does } \\
\text { not interfere } \\
\text { with portfolio } \\
\text { management }\end{array}$ & Not performed \\
\hline Social relevance & Necessary & \multicolumn{3}{|c|}{ Not applicable } \\
\hline Financial return & Necessary & Necessary & Necessary & Necessary \\
\hline Sanitary legislation & $\begin{array}{c}\text { Does not interfere } \\
\text { with portfolio } \\
\text { management }\end{array}$ & $\begin{array}{c}\text { Does not interfere } \\
\text { with portfolio } \\
\text { management }\end{array}$ & $\begin{array}{c}\text { Does not interfere } \\
\text { with portfolio } \\
\text { management }\end{array}$ & $\begin{array}{c}\text { Does not interfere } \\
\text { with portfolio } \\
\text { management }\end{array}$ \\
\hline Raw material availability & $\begin{array}{l}\text { Does not interfere } \\
\text { with portfolio } \\
\text { management }\end{array}$ & Necessary & Necessary & Necessary \\
\hline Technical success & Desirable & Desirable & Desirable & Necessary \\
\hline
\end{tabular}

FIGURE 4 - Classification of key criteria in the assessed companies.

did not participate in the selection of the development projects. The official laboratory made the company's business strategy clear. Only one private company expressed this concern. All the assessed companies showed an interest in following an Analyzer strategy, based on the concept by Griffin and Page (1996). The companies presented a PDP focused on the Product Development sector.

Regarding key criteria for portfolio management of Brazilian pharmaceutical companies, the classification presented in Figure 4 was verified for each company.

None of the companies demonstrated use of patent monitoring data for selection of new product projects. All the products launched by the assessed companies had patents that expired more than two years previous. For the private companies, financial return was the main criterion for selection of new product development projects, while the main criterion for the official laboratories was social relevance.

The case studies have demonstrated that compliance with sanitary legislation did not interfere with the selection of projects, since the private companies already had the necessary infrastructure to meet sanitary requirements. The official laboratory assessed was being reformed to modernize its infrastructure. Product launch time was critical for the private companies. The criterion "raw material availability" was found to be the most important factor in the selection of new product projects for the private companies. Technical success was a criterion evaluated after selection of the project and was used to help prioritize the projects. However, projects cannot be aborted based on this criterion. The assessed companies held product development follow-up meetings, but there was no discussion about the selected and prioritized projects, as indicated in the results of the case study.

Several key criteria have been identified for the selection of new product projects in the assessed companies. However, the absence of structured application of the criteria was clear. The selection of new product projects was made based on the tacit knowledge of the company owner. It is noteworthy that the assessed companies are currently implementing a product development process.

The case studies have fulfilled the purpose of exploring the theme of new product portfolio management in Brazilian pharmaceutical companies. The results have provided input for the development of a managerial standard for new product portfolio management in Brazilian pharmaceutical companies.

\section{Proposal of a managerial standard for new product portfolio management in brazilian pharmaceutical companies}

As discussed in the introduction, the portfolio management model proposed by Cooper, Edgett and Kleinschmidt (1998) presents some characteristics (for example, practicality and simplicity) that make it more suited to the application of new product portfolio management for companies that do not yet formally use this type of management. The case study results have been incorporated into the model to produce a proposal of a managerial standard for portfolio management in Brazilian pharmaceutical companies.

The cases have shown that the Brazilian pharmaceutical companies assessed had no structured portfolio management. The projects were selected by the company's 
top management with little influence from other sectors. Another characteristic was the number of new product projects developed simultaneously. The companies often had no specific priority, but a group of priorities from which any project carried out must first meet the corporate goals. Another important aspect is the lack of a clear definition of the strategic purposes for development of new products. These main aspects have been taken into consideration in the managerial standard developed.

A managerial standard here is defined as a standardized procedure for implementation of a process. This paper proposes a simple structure model for implementation of new product portfolio management in Brazilian companies. This proposal can be regarded as the first level of evolution of the portfolio management in companies adopting a managerial standard. Following the implementation of the proposed model, improvement in portfolio management and, consequently, in Product Development
Management, should take place naturally.

The managerial standard for application of new product portfolio management in Brazilian pharmaceutical companies is centered on four basic principles:

a) Formation of the PDM team,

b) Definition of product development strategy,

c) PDP management,

d) Revision of the portfolio.

The principles depicted in Figure 5 were structured to illustrate the interaction among them. The application of each principle is described below. The purposes of portfolio management in the Brazilian pharmaceutical industry are the same as those for other companies, as defined by Cooper, Edgett and Kleinschmidt (1998): strategic alignment, maximized value, and balancing. To facilitate the operation of the portfolio management process, the use of a Portfolio Management Work Spreadsheet is suggested for recording and displaying the evaluations.

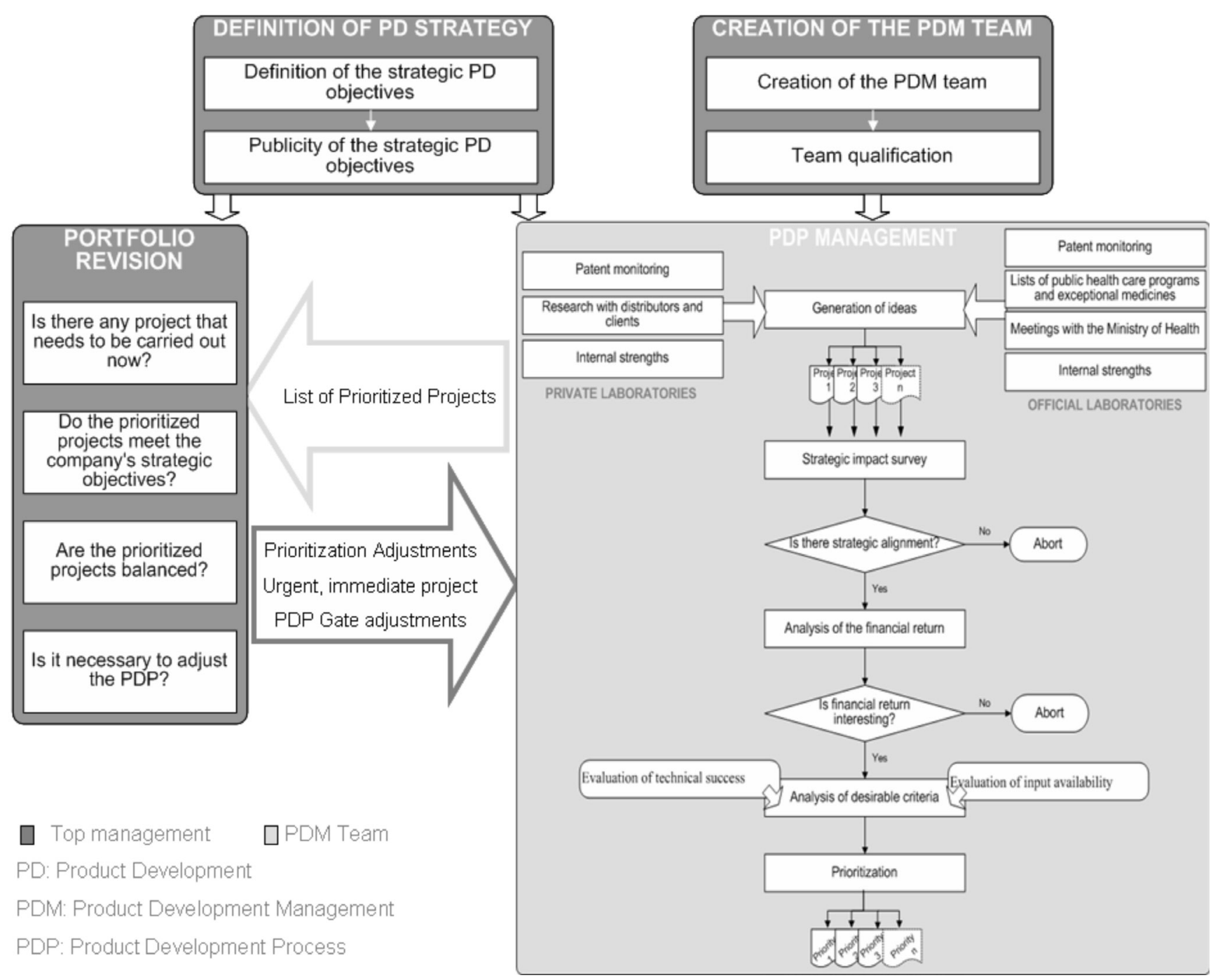

FIGURE 5 - Proposal of managerial standard for new product portfolio management in Brazilian pharmaceutical companies. 
a) Forming product development management team

The first step toward application of portfolio management is to build a team. The company's top management should set up a multidisciplinary team. The team should have representatives that can perform the responsibilities described in Figure 6. The bundling of several responsibilities can be an alternative when the company is medium sized - for example, the top management can be responsible for the financial activities while the project management can oversee the product development sector.

It is recommended that the team comprises 3 to 8 members each dedicating at least $10 \%$ of their working hours to portfolio management. This team is not responsible for the execution of the project itself. To make the product, the project management should appoint a team consisting of technical professionals fully dedicated to the execution of the project. The team should be qualified to carry out their functions.

\section{b) Definition of product development strategy}

The definition of the product development strategy is the framework that shall guide the other principles in portfolio management. As the Brazilian pharmaceutical companies assessed did not clearly present the product development strategy, it is suggested that the strategic new product development objectives should be directly deployed from the business strategy. Using this approach, the company's top management can present the Product Development Management team with what is expected from the product launches in a direct and summarized

\begin{tabular}{|c|c|c|c|c|c|c|c|c|c|c|}
\hline $\mathrm{Nr}_{\mathrm{N}}^{\mathrm{ra}}$ & 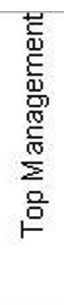 & 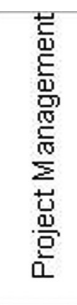 & 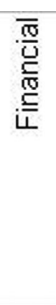 & 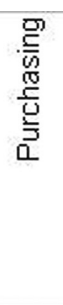 & 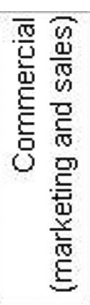 & 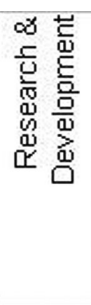 & 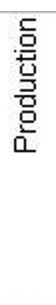 & 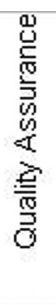 & 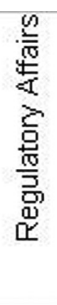 & 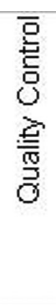 \\
\hline Definition of new product strategy & - & 0 & 0 & 0 & 0 & 0 & 0 & 0 & 0 & 0 \\
\hline Portfolio revision & - & $\circ$ & 0 & 0 & $\odot$ & ० & 0 & 0 & 0 & 0 \\
\hline Definition of Product Development Management budget & 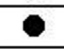 & 0 & 0 & & & & & & & \\
\hline Appointment of the PDM team & - & 0 & & & & & & & & \\
\hline Scheduling of Gate meetings & 0 & - & 0 & 0 & 0 & 0 & 0 & 0 & 0 & 0 \\
\hline Decision making during the PDP & 0 & - & $\odot$ & $\odot$ & $\odot$ & $\circ$ & $\odot$ & $\odot$ & $\odot$ & $\odot$ \\
\hline Ensure compliance with the project requirements & 0 & - & & & & $\odot$ & & - & $\odot$ & \\
\hline Purchase of input & 0 & 0 & 0 & - & & 0 & 0 & & & 0 \\
\hline Evaluation of the product analysis capacity & 0 & 0 & & & 0 & 0 & 0 & 0 & & - \\
\hline Evaluation of the impact on the GMPNalidation Program & 0 & 0 & & & & 0 & 0 & - & $\odot$ & 0 \\
\hline Regulatory evaluation of the project & 0 & 0 & & & & 0 & 0 & 0 & - & 0 \\
\hline Supplier qualification & 0 & 0 & & $\bullet$ & & ○ & O & ○ & 0 & $\circ$ \\
\hline Evaluation of the productive capacity of the new product & 0 & $\circ$ & & & 0 & $\circ$ & - & 0 & & 0 \\
\hline Technical evaluation of the project & 0 & $\odot$ & & & 0 & - & ○ & 0 & 0 & $\odot$ \\
\hline New product launching program management & 0 & $\circ$ & & & e & & & & 0 & \\
\hline Creation of team for each project & O & - & 0 & 0 & 0 & o & 0 & 0 & 0 & 0 \\
\hline Market research & $\circ$ & 0 & 0 & & e & 0 & & & & \\
\hline Sale estimation & $\circ$ & 0 & 0 & 0 & $\bullet$ & & 0 & & & 0 \\
\hline Analysis of new product cost and profitability & $\odot$ & $\odot$ & - & & $\odot$ & $\odot$ & $\odot$ & & & \\
\hline Budget data supply & O & $\circ$ & e & & & & & & & \\
\hline Idea survey & $\circ$ & $\odot$ & $\circ$ & O & - & O & $\odot$ & $\%$ & $\circ$ & \% \\
\hline Technical problem solution & & 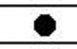 & & & & O & & & & \\
\hline ANVISA product registration & & 0 & & & & & & & - & \\
\hline Product follow-up during industrial production & & 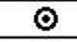 & & & & ○ & - & & & \\
\hline Research on input availability & & ○ & & - & & $\odot$ & & & & \\
\hline Preparation of graphic material for the product & & $\odot$ & & & - & & & & \% & \\
\hline Realization of the product and involved documentation & & o & & & & - & & & $\odot$ & \\
\hline Product quality follow-up during industrial production & & & & & & & & $\odot$ & & - \\
\hline & $\begin{array}{l}1 \\
0 \\
0\end{array}$ & $\begin{array}{l}\text { Partic } \\
\text { Inforn }\end{array}$ & & & & & & & & \\
\hline
\end{tabular}

FIGURE 6 - Responsibility matrix of PDM team representatives. 
manner. The current level of maturity of the companies assessed hindered the deployment of the new product development strategy from the business strategy.

The official laboratories must take into consideration the strategic objectives related to Social Relevance which can entail the development of new drugs for rare or neglected diseases, vaccines, medicines for primary pharmaceutical care, or phytotherapeutic substances.

The definition of strategic objectives is essential to structure portfolio management and can be performed by the Brazilian pharmaceutical industry. The top management should present the new product development objectives in a direct and summarized manner. This facilitates the communication of the objectives and confers flexibility to the top management, which can prioritize some objectives over time and revise them annually. The company's new product development strategy should be defined upon the evolution of the Product Development Management. It is suggested that the strategy typology classification proposed by Griffin and Page (1996) be followed. Based on the strategy selected by the company, balancing the projects by project typology will contribute toward attaining the portfolio management objectives. For example, if a company defines that its new product development strategy is to be a pioneer among the Brazilian pharmaceutical companies and be an analyzer among the multinational pharmaceutical companies, then most of its projects should be related to new generic medicines in the home market. When the projects are classified by type, the project typology should be added to the work spreadsheet, in order to associate this with the strategic objective and provide data for evaluation of project balance.

\section{c) PDP Management}

PDP Management is the operational principle of portfolio management. During the product development process, the new product project shall be submitted to an evaluation process that determines its feasibility and priority.

This portfolio management application procedure consists of a simple, practical structure for evaluation of new product projects by the PDM team. The difference between the process performed by the private industry and that performed by the official laboratory is the idea of generating source. The PDP Management steps are described below.

i) Stage: generation of ideas

The generation of ideas is the beginning of the PDP process and should be performed considering the internal and external environment. The sources of ideas that yield greatest benefits with least investment of effort should be considered. The main idea generating sources for a private company consists of the monitoring of patents, market research with distributors, feedback from clients, and evaluation of internal strengths. The official laboratories should substitute the supplier surveys and feedback from clients, with the lists of medicines provided by the public health programs, together with data on distribution of exceptional medicines and meetings held by the Ministry of Health and Health Secretariats.

The monitoring of patents can be performed by specific databases or by service providers. The companies should search for information on the patents set to expire within the next 10 years. The official laboratories can extract possible candidate drugs for future use in public health programs from patents to be expired and discuss them in meetings with the Ministry of Health.

Market research with distributors, who are the primary clients of the private companies, should provide data on the sales of a given product and prospective markets. The secondary clients, who are the drugstore owners, should provide ideas about improvements in existing products, either in the packaging or regarding the associations of products. This market research should be performed by the company's sales team during routine visits. The use of a questionnaire is suggested for the sales professional to search for important information and to later generate ideas from all the clients visited. A survey by Client Support can also produce ideas for improvement.

The official laboratories should search for data on the distribution of health program medicines and exceptional medicines. Periodical meetings can be held between professionals of the public health sector and government members. The lists of health program medicines can be discussed in these meetings. The official laboratories should participate in these meetings by seeking ideas on new products for use by the public health programs.

Research into internal strengths should be performed in order to seek ideas that can result in quick gains. The existing technical knowledge, the underutilization of equipment, the product return rates and other issues should be investigated. This research can, for example, indicate an innovative line of products from the technical knowledge of a certain professional of the company. Research into internal strengths should be performed by professionals with an enterprising vision. It is suggested that the top management perform this research half-yearly.

ii) Stage: Survey of strategic impact

The survey of the strategic impact on the Brazilian pharmaceutical industry should be performed by the top management and the PDM team. Each idea proposed should be discussed taking into account its impact on the 
company's strategic objectives. In the official laboratories, the Social Relevance criterion must be analyzed in this step, since the mission of these companies is to contribute to the growth of the Public Health System.

Each idea should be assigned a score representing the impact on a given strategic objective where each idea can also be classified as high, medium or low impact for the strategic objective. This step consists of a survey, and involves no decision making. The impact is evaluated at each consecutive step, which in practice can be done at the same meeting as that of the survey of the strategic impact.

iii) Gate: Screening 1 - Evaluation of strategic impact

The evaluation of the strategic impact on the Brazilian pharmaceutical industry should be performed by the company's top management in this implementation of the portfolio management model. The evaluation by the top management shall be recorded and communicated to the portfolio management team in order to build a knowledge base in the company. The evaluation must next be performed by the portfolio management team, where the top management shall only be responsible for the Portfolio Revision.

The evaluation of the strategic impact shall classify each project as high, medium or low impact or add/multiply the score of the previous step. In this step projects may be aborted should their idea not be aligned with the strategic objectives.

iv) Stage: Analysis of financial return

Financial return must be analyzed at the outset of the project classification process. There are several methods to calculate the financial return of projects. The application of simple methods, which can evolve with time, is suggested in the implementation of the portfolio management model, according to the example outlined below.

At this initial stage, companies can analyze the financial return based on the calculation of the reference medicine formulation cost and its maximum price. The maximum price of the new product takes into consideration the prices of the competing medicines. The drugstore's margin, distributor's margin and manufacturer's margin of profit are deducted from the maximum price, thus reaching a maximum cost for comparison against the manufacturing cost. Since the financial analysis is performed at the outset of the process, the team should use the reference medicine for calculation of the manufacturing cost. To survey estimated demand, the team should conduct research with distributors in order to ascertain the sales of the competing medicines. From these data it is possible to evaluate the financial feasibility of the product. Should there be no reference medicine, the definition of a theoretical formu- la for the product will be required, where this formula should be proposed by the pharmaceutical development professionals.

The official laboratories should be attentive to the financial return. As they are public institutions they run the risk of disregarding financial calculations essential to the survival of the company. Instead of the abovementioned research with distributors used by the private companies, the official company should draw on data regarding distribution of the product by the public health services.

The highest investment in the development of a similar/generic pharmaceutical product is usually the costs of the relative bioavailability/bioequivalence test. During the analysis of the financial return, it should be evaluated whether there will be additional investments that impact the product development cost.

v) Gate: Screening 2 - Evaluation of financial return

To evaluate the financial return, the top management needs to define the minimum demand which would make the product an interesting commercial proposition for the company. The manufacturing cost calculated should be lower than the target cost. The case studies have demonstrated that at present, the top management lacks information on financial return values. Therefore, the company can initially choose to delegate the responsibility for this step to the top management, which should classify the financial return as high, medium or low. This screening enables aborting of projects considered non-profitable in the evaluation of the financial return.

vi) Stage: Analysis of desirable criteria

This step consists of the analysis of criteria which are important to the company, such as technical success and availability of raw material. The results of the case studies show that these two criteria were essential to the selection of projects in the assessed companies. The participation of the PDM team is intense in this step. The analysis of these criteria will contribute to the selection of the projects and, consequently, to the progress of the PDP.

The technical success is analyzed by the technical professionals, including the pharmaceutical development, production, quality control, quality assurance and regulatory affairs sectors. The use of a checklist to guide this analysis is suggested. An example checklist is presented in Figure 7. Prior to its application, the company should adapt the list to suit its specificities, taking into account the items assessed, the weights assigned and the scoring scale.

The availability of raw material should be taken into consideration since it represents a factor determining total development time. The evaluation of this item requires the full participation of the purchasing sector and a technical representative to evaluate aspects related to supplier 


\begin{tabular}{|c|c|c|c|c|}
\hline Classification & Item assessed & $\begin{array}{c}\text { Yes } \\
\text { (5 pts) }\end{array}$ & $\begin{array}{c}\text { No, } \\
\text { requiring } \\
\text { little effort } \\
\text { (3 pts) }\end{array}$ & $\begin{array}{c}\text { No, } \\
\text { requiring } \\
\text { a lot of } \\
\text { effort } \\
\text { (1 pt) }\end{array}$ \\
\hline \multirow{6}{*}{$\begin{array}{l}\text { Pharmacological- } \\
\text { technical and } \\
\text { quality control } \\
\text { aspects }\end{array}$} & $\begin{array}{l}\text { Are there other products with the same } \\
\text { pharmaceutical form? }\end{array}$ & & & \\
\hline & $\begin{array}{l}\text { Is the active substance analysis methodology } \\
\text { pharmacopoeic? }\end{array}$ & & & \\
\hline & $\begin{array}{l}\text { Are there other products that use the same } \\
\text { excipients? }\end{array}$ & & & \\
\hline & $\begin{array}{l}\text { Are there other products that use the same } \\
\text { packaging materials? }\end{array}$ & & & \\
\hline & $\begin{array}{l}\text { Do the relative bioavailability/bioequivalence } \\
\text { tests follow the standard (that is, there are no } \\
\text { features that hinder the process)? }\end{array}$ & & & \\
\hline & $\begin{array}{l}\text { Does the validation of the process follow the } \\
\text { standard (that is, there are no features that } \\
\text { hinder the process)? }\end{array}$ & & & \\
\hline \multirow[t]{6}{*}{$\begin{array}{l}\text { Infrastructure } \\
\text { aspects }\end{array}$} & $\begin{array}{l}\text { Is there infrastructure (equipment, area, utilities, } \\
\text { etc.) for the industrial production? }\end{array}$ & & & \\
\hline & $\begin{array}{l}\text { Is there infrastructure (equipment, area, utilities, } \\
\text { etc.) for the development? }\end{array}$ & & & \\
\hline & $\begin{array}{l}\text { Is there infrastructure (equipment, area, utilities, } \\
\text { etc.) for the stability assessments? }\end{array}$ & & & \\
\hline & $\begin{array}{l}\text { Is there infrastructure (equipment, area, utilities, } \\
\text { etc.) for the industrial production? }\end{array}$ & & & \\
\hline & $\begin{array}{l}\text { Is there infrastructure (equipment, area, utilities, } \\
\text { etc.) for the quality control? }\end{array}$ & & & \\
\hline & $\begin{array}{l}\text { Does the current productive capacity } \\
\text { accommodate the new product? }\end{array}$ & & & \\
\hline \multirow{3}{*}{$\begin{array}{l}\text { Regulatory } \\
\text { aspects } \\
\text { Weight: } 1\end{array}$} & $\begin{array}{l}\text { Does the regulatory register dossier follow the } \\
\text { standard format (that is, there are no features } \\
\text { that hinder the process)? }\end{array}$ & & & \\
\hline & Is the new product in conformity with the GMP? & & & \\
\hline & $\begin{array}{l}\text { Is the new product in conformity with the safety } \\
\text { standards? }\end{array}$ & & & \\
\hline
\end{tabular}

FIGURE 7 - Checklist for evaluation of technical success.

qualification. The decision tree presented in Figure 8 is a tool to evaluate the availability of raw material. The difference between manufacturer and distributor is noteworthy. The manufacturer is a company that manufactures raw material. The raw material can be sold directly, either to a pharmaceutical company or to an intermediate agent, which is the distributor.

vii) Gate: Prioritization

This step is the consolidation of the PDP Management principle. As the pharmaceutical companies deal with several development projects simultaneously, prioritiza- tion by groups is suggested. The Priority 1 group should include the projects considered essential to the company. There should also be prioritization within each group to organize the sequence of work.

Prioritization should take into consideration the balancing of projects. Some criteria which are important to balance the projects, such as impacted strategic objective, product family or type of project, should be used.

d) Portfolio revision

The Portfolio Revision entails a periodical evalua- 


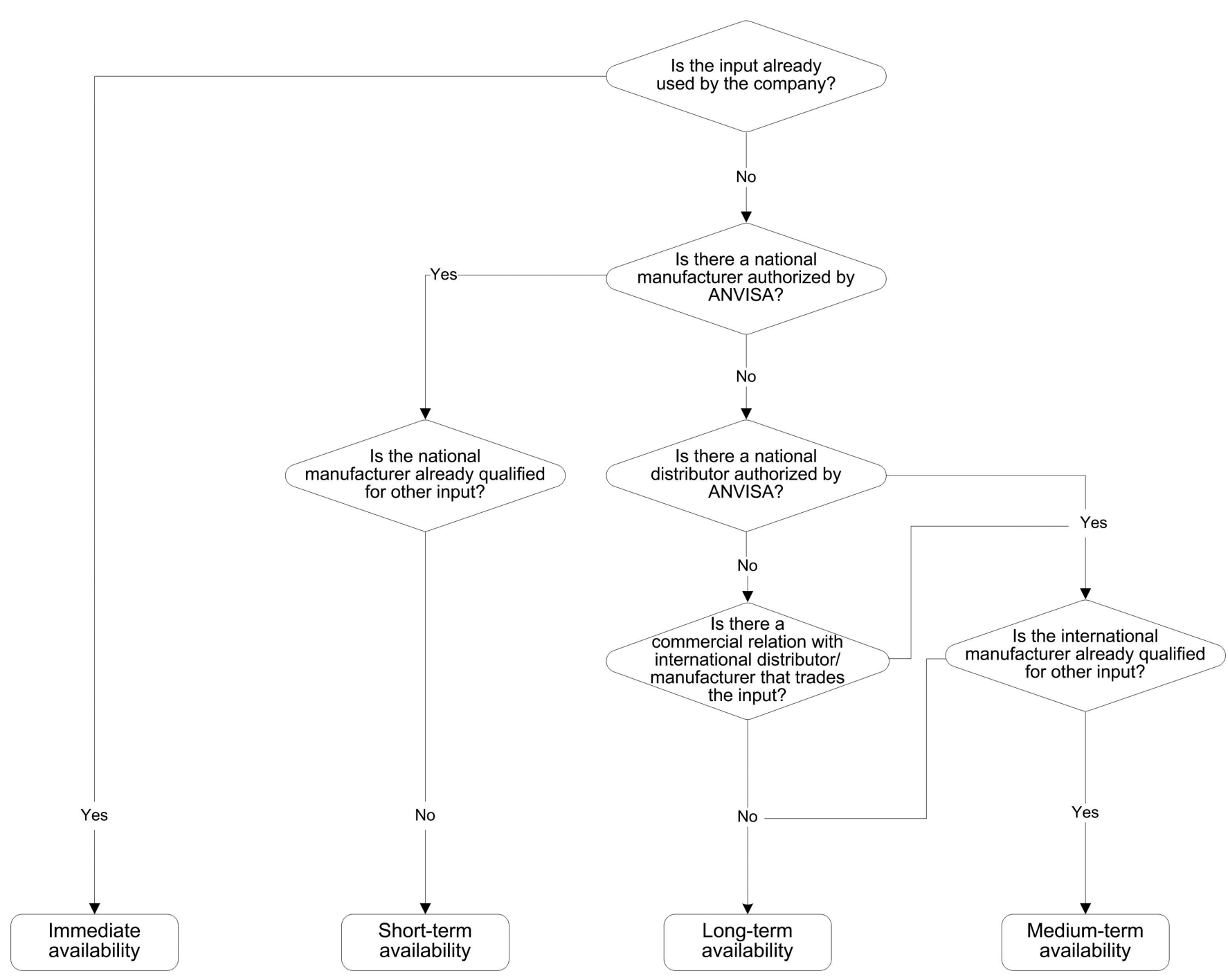

FIGURE 8 - Decision tree for evaluation of raw material availability.

tion by the Top Management of the projects included in each Priority Group. A quarterly revision is suggested in the first two years of application of the portfolio management. From the third year on, a half-yearly revision is suggested. The portfolio revision should be planned by the Product Development management.

The Portfolio Revision process consists of answering the following questions:

$1^{\text {st }}$ ) Is there any project that needs to be carried out now? $2^{\text {nd }}$ ) Do the prioritized projects meet the company's strategic objectives?

$3^{\text {rd }}$ ) Are the prioritized projects balanced?

$\left.4^{\text {th }}\right)$ Is it necessary to adjust the PDP?

In discussing the first question, the portfolio revision team can request a certain project to be prioritized due to recent information acquired on the same product being launched by a competitor or because the sale of another product depends on this new product. The second question should be discussed to confirm that the PDM team understands the company's strategy and is able to translate it into new products. The project balancing discussed in the third question may take several criteria into consideration. It is important that the criteria used for balancing during the Portfolio Revision are the same as those used by the PDM team. During the Portfolio Revision, new criteria important for portfolio management can be identified. These criteria shall be immediately informed to the portfolio management team for adjustment of the PDP, thus answering the fourth question. The Portfolio Revision should use tools to facilitate the analysis by the top management, such as bubble diagrams. As explained by Cooper, Edgett and Kleinschmidt (1998), the portfolio revision can become a mere formalization of the portfolio management, and no adjustments will be required after the revision. This may occur in the Brazilian pharmaceutical companies assessed as the knowledge base of the PDM 
team enlarges and the portfolio management becomes truly implemented in the company.

\section{CONCLUSION}

This research has produced a proposal of a managerial standard for new product portfolio management in Brazilian pharmaceutical companies, based on revision of the literature and results of case studies. An absence of references on this theme for Brazilian companies was noted during the review of literature. Selection and prioritization papers using quantitative methods for innovative medicines are more frequent. Since this scenario is unlikely in the Brazilian pharmaceutical industry for the foreseeable future, a theoretical portfolio management model was elected to serve as a conceptual basis for these case studies.

The proposal of a standard for application of new product portfolio management in Brazilian pharmaceutical companies is managerial, systemic and flexible: i) it is managerial because it possesses the tactical/operational and strategic dimensions in a manner allowing its application to lead to continuous evolution of Product Development Management; ii) it is systemic because it interconnects the components of Product Development Management and requires a multidisciplinary team; iii) it is flexible because it can be adapted to accommodate different companies and stages of evolution and allows the use of different methods and tools.

Although the managerial standard presents a structure for practical application, it is still theoretical since it has not yet been submitted to evaluation or implementation in the companies. It is important to note that the managerial standard embraces characteristics of the similar and generic medicine industry that deal basically with incremental research. Innovative research into new medicines is not covered by this managerial standard.

\section{REFERENCES}

AGÊNCIA NACIONAL DE VIGILÂNCIA SANITÁRIA. ANVISA. Relatório de atividades 2006. Available at: <www.anvisa.gov.br>. Accessed on: 07 sep. 2007.

AGÊNCIA NACIONAL DE VIGILÂNCIA SANITÁRIA. ANVISA. Apostila de Seminário Medicamentos Genéricos. Belo Horizonte: Associação Médica de Minas Gerais, 2002. p.65.

ARCHER, N. P., GHASEMZADEH, F. An integrated framework for project portfolio selection. Int. J. Proj. Manag., v.17, n.4, p.207-216, 1999.
BITMAN, W. R., SHARIF, N. A. Conceptual framework for ranking R\&D Projects. IEEE Trans. Eng. Manag., v.55, n.2, p.267-278, 2008.

BITMAN, W. R. R\&D Portfolio management framework for sustained competitive advantage. Proc. IEEE Int. Eng. Manag. Conf., v.2, Set. 11-13, p.775-779, 2005.

BLAU, G. E.; GARY E., PEKNY, J. F., VARMA, V. A., BUNCH, B. R. Managing a Portfolio interdependent new product candidates in the pharmaceutical industry. J. Prod. Innov. Manag., v.21, n.21, p.227-245, 2004.

COOPER, R. G.; EDGETT, S. J.; KLEINSCHMIDT, E. J. Portfolio management in new product development: Lessons from the leaders - I. Res. Technol. Manag., v.40, n.5, p.16-28, 1997.

COOPER, R. G.; EDGETT, S. J.; KLEINSCHMIDT, E. J. Portfolio management for new products. Massachusetts: Addison-Wesley, 1998. $230 \mathrm{p}$.

CORREIA, B. C. S. Portfolius: Um modelo de gestão de portfólio de projetos de Software. Recife, 2005. 99p. [Master's Degree Thesis in Computer Science. Universidade Federal de Pernambuco].

COSTELLO, D. A practical approach to R\&D project selection. Technol. Forecast. Soc. Change, v.23, n.4, p.353-368, 1983.

EUROPEAN FEDERATION OF PHARMACEUTICAL INDUSTRIES ASSOCIATION. EFPIA. New medicines approved for use in the European Union in 2000 and, 2004. Available on: <www.efpia.org>. Accessed on: 21 jun. 2005.

GRIFFIN, A. PDMA Research on new product development practices: Updating trends and benchmarking best practices. J. Prod. Innov. Manag., v.14, n.6, p.429-458, 1997.

GRIFFIN, A., PAGE, A. PDMA success measurement project: recommended measures for product development success and failure. J. Prod. Innov. Manag., v.13, n.6, p.478-496, 1996.

HALL, D. L., NAUDA, A. An interactive approach for selecting IR\&D projects. IEEE Trans. Eng. Manage., v.37, n.2, p.126-133, 1990.

HEIDENBERGER, K.; STUMMER, C. Research and development project selection and resource allocation: a review of quantitative modeling approaches. Int. J. Manag. Rev., v.1, n.2, p.197-224, 1999. 
INTERNATIONAL FEDERATION OF PHARMACEUTICAL MANUFACTURERS ASSOCIATIONS. IFPMA. $A$ plataforma de inovação farmacêutica - sustentar uma saúde melhor para os doentes em todo o mundo, 2004. Available on <www.ifpma.org $>$. Accessed on: 21 jun. 2005.

KAVADIAS, S. Project portfolio selection and resource allocation in new product development. Fointanebleau, 2001. 146 p. [Dissertation in Management. Institut Européen d'Administration des Affaires - European Institute of Business Administration - INSEAD].

LOCH, C. H.; KAVADIAS, S. Dynamic portfolio selection of NPD programs using marginal returns. Manag. Sci., v.48, n.10, p.1227-1241, 2002.

MIKKOLA, J. H. Portfolio management of R\&D projects: implications for innovation management. Technovation, v.21, p.423-435, 2001.

MOREIRA, R. A. Proposta de um padrão gerencial de gestão de portfólio de novos produtos para Indústria Farmacêutica nacional. Belo Horizonte, 2008. 145p. [Master's Degree Thesis in Production Engineering. Engineering College. Federal University of Minas Gerais].

OLIVEIRA, G. N. Construindo um sistema de desenvolvimento de produtos em empresa têxtil por intermédio da Gestão de Portfólio e QFD. Belo Horizonte, 2007. 188 p. [Master's Degree Thesis in Production Engineering. Engineering College. Federal University of Minas Gerais].

OLIVEIRA, M. G.; ROZENFELD, H. Desenvolvimento de um modelo para priorizar projetos de desenvolvimento de produtos. In: BRAZILIAN CONGRESS ON PRODUCT DEVELOPMENT MANAGEMENT, Belo Horizonte, 6 , 2007. Anais. Belo Horizonte: Universidade Federal de Minas Gerais, 2007. (CD-Rom).
PEREIRA, A. R. Modelo de gestão de portfólio para alinhar os projetos de novos produtos às estratégias corporativas. Florianópolis, 2002. [Master's Degree Thesis in Production Engineering. Federal University of Santa Cantarina].

ROUSSEL, P. A.; SAAD, K. N.; BOHLIN, N. Pesquisa \& desenvolvimento: como integrar $\mathrm{P} \& \mathrm{D}$ ao plano estratégico e operacional das empresas como fator de produtividade e competitividade. São Paulo: Makron, 1992. 198 p.

SANTIAGO, L. P.; VAKILI, P. R\&D Management: optimal project selection and budget allocation for $\mathrm{R} \& \mathrm{D}$ portfolios. In: ANDERSON, T. R.; DAIM, T. U.; KOCAOGLU, D. F.; MILOSEVIC, D. Z.; WEBER, C. M. (Orgs.). Technology management: a unifying discipline for melting the boundaries. Piscataway: IEEE \& PICMET, 2005. v.1. p.275-281.

THE BOSTON CONSULTING GROUP. The changing environment for US pharmaceuticals: the role of pharmaceutical companies in a systems approach to health care. Boston: Editora, 1993. 98 p.

YIN, R. K. Estudo de caso: planejamento e métodos. 3.ed. Porto Alegre: Bookman, 2005. 212 p.

Received for publication on $09^{\text {th }}$ July 2008 Accepted for publication on $25^{\text {th }}$ June 2009 